\title{
Differences of gender in HIV- Risky Sexual Behavior among Adolescents and Parental Support in Luwuk City
}

\author{
Ramli $^{1}$, Fitrianty S. Lanyumba ${ }^{1}$, Marselina Sattu ${ }^{1}$, \\ Winnie Tunggal Mutika ${ }^{2}$, Erni Yusnita Lalusu ${ }^{1}$, Ahmad Yani $^{3}$

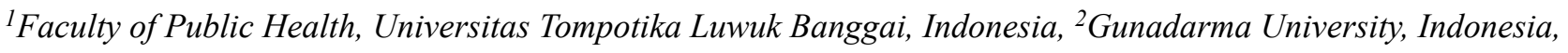 \\ ${ }^{3}$ Faculty of Public Health, Universitas Muhammadiyah Palu, Indonesia
}

\begin{abstract}
The proportion of HIV AIDS prevalence currently continues to increase and disparate between women and men. Aim: to obtain an overview of HIV-risky sexual behavior among adolescents based on gender and parental support. This study was conducted using a cross-sectional study design on 385 adolescents $(\mathrm{P}=50 \%)$ aged 15-18 years in high schools throughout Luwuk City selected through accidental sampling techniques. Adolescent sexual behavior and parental support were assessed using the Indonesia Global school-based student health survey (GSHS) Questionnaire. There were 26 adolescents $(6.8 \%)$ had intercourse, men= 22 $(85 \%)$ and women $=4(15 \%) .9$ adolescents $(2.3 \%)$ had sex for the first time at age $\leq 11$ years and $7(1.9 \%)$ did it with four or more partners. 8 male adolescents $(5.8 \%)$ and 1 female $(0.4 \%)$ had intercourse with men and women (bisexual) and $48.8 \%$ of female adolescents did not know how to refuse an invitation to have sex. Parental support like communication is more frequent in females $(39 \%)$ than males $(33 \%)$. Better understand the problems of females (43.1\%) than males (41.8\%). There are still $10 \%$ of parents demeaning/ dropping other males and 6\% female. Most of the risky sexual behavior is found between male, while the support and attention of parents are mostly directed to female. There are needs to develop health education in elementary school to high school and counseling to parents.
\end{abstract}

Keywords: Sexual Behavior, Parental Support, Gender, Adolescent.

\section{Introduction}

Adolescence is a period of rapid growth and development both physically, psychologically and intellectually. The nature of adolescents has a great sense of curiosity, likes adventure, challenges and tends to dare to bear the risk of his actions without prior consideration.

Teenagers are residents in the age range of $10-19$ years (WHO) ${ }^{(1,2)}$ The adolescent group accounts for $18 \%$ of the total population, which means that a fifth percent of the Indonesian population is adolescents and thus it

\section{Corresponding Author: \\ Ramli \\ Faculty of Public Health, Universitas Tompotika \\ Luwuk Banggai, Indonesia \\ e-mail: : ramli.bidullah@gmail.com}

becomes a threat regarding risky sexual behavior. ${ }^{(1)}$

The adolescent age group is one of the starting point phases of numerous health problems, including HIV and AIDS $^{(2)}$. As per the report of Risk and Protection: Youth and HIV/AIDS in Sub-Saharan Africa (2004), that adolescents and young adults who have sexually active are at greater risk than adults exposed to HIV, partly due to lack of knowledge and stimulation of sexual intercourse. ${ }^{(3-6)}$

Parental support is one pivotal factor in the formation of adolescent behavior ${ }^{(7)}$. Several studies conducted in the adolescent age group have identified determinants of sexual behavior. Majority of this study that studied sexual behavior in Ethiopian teenagers already described potential contributors of adolescent sexual behavior such as awareness or attitude toward the risks of HIV and AIDS and communication of both parents and teenagers about health reproduction ${ }^{(8)}$. 
Numerous studies showed different proportions of HIV and AIDS prevalence between males and females. Consequently, there is a need to analyze the gender difference with respect to determinants and sexual behavior among adolescents to determine effective intervention strategies. Therefore, this present study aimed to describe adolescent's sexual behaviors and parental support by gender

\section{Method}

This present study was a cross-sectional study design conducted in four high schools (SMAN) in Luwuk City in May-June 2018. The population of the study was all high school students of $1^{\text {st }}, 2^{\text {nd }}$ and $3^{\text {rd }}$ grades. The number of samples was 385 students calculated using a proportion of $50 \%(\mathrm{P}=0.5)$. samples were selected through an accidental sampling technique. Adolescent sexual behaviors and parental supports were assessed using Indonesia's Global school-based student health survey (GSHS) Questionnaire. As many as 20 enumerators were students at the Public Health Faculty of Tompotika University, Luwuk. Prior to the study, a training was given to enumerators as well as preparing survey instruments. Surveys were carried out at different times. Data collection for SMKN 1 Luwuk was completed on May 22, 2018. Data collection at SMAN1 Luwuk and SMAN 3 Luwuk was completed from May 30 to May 31, 2018. Meanwhile, data collection for SMAN 2 Luwuk was carried out on June 4, 2018.

\section{Results and Discussion}

\section{Table 1. Adolescent Characteristics in Luwuk City}

\begin{tabular}{|l|c|}
\hline Variable & N (\%) or Mean (SD) \\
\hline Gender & $139(36.1)$ \\
Males & $246(63.9)$ \\
Females & $16.2(0.9)$ \\
\hline Age & \\
\hline Father's Occupation & 15 \\
Civil Servant & 31 \\
Private sector worker & 262 \\
Entrepreneur & 64 \\
Farmer & 8 \\
Fisherman & 5 \\
Household Mothers & $2,181,000(2,245,036)$ \\
\hline Family Income &
\end{tabular}

Adolescence is a period of transition from childhood to adulthood. It is characterized by rapid physical changes, dramatic weight and height gains, changes in body shape and development of sexual characteristics such as enlargement of the breasts, development of the waist and mustache and depth of sound. This raises the interest of the opposite sex. In this development, the achievement of independence and identity is very prominent (increasingly logical, abstract and idealistic thinking) and more time is spent outside the family $(1,2)$

The increasing prevalence of risky sexual behavior in Indonesia within a 5-year-period can be due to several factors including increasingly difficult life that requires both parents to work harder so they do not pay attention to their teenage children. In this study (Table 1) majority of the respondent's father's occupation are entrepreneurs such as salesmen, drivers, shipmen, building workers, etcetera. These types of working do not have fixed working time and tend to spend more time outside the home. Consequently, this also reduces the time to interact with the child. Under an economic perspective, the findings of this study indicate that the average family income is quite high (above the provincial minimum wage). Therefore, economic factors seem not to be a determinant in the formation of risky sexual behavior among adolescents.

Extramarital sex develops numerous negative impacts, such as unwanted pregnancy, decreased learning achievement, dropping out of school, depression and even increased suicide rates among adolescents $(9,10)$ the extramarital sex phenomenon among adolescents continues to increase. National data shows the greatest proportion of dating for the first time at the age of 15-17 years ${ }^{(1)}$. At this age, concerns about not having life skills and appropriate knowledge are raised and thus adolescents are at great risk of engaging in unhealthy sexual behavior including extramarital sexual intercourse. In this present study, as many as 26 adolescents $(6.8 \%)$ that are mostly males have had extramarital sex. Of those numbers, 9 adolescents $(2.3 \%)$ had extramarital sex at the age of elementary school $((\leq 12$ years old. Furthermore, 7 adolescents $(1,9 \%)$ had sexual intercourse with $\geq 4$ partners and 9 teenagers $(2,3 \%)$ had sexual intercourse with both males and females (bisexual). Rates of condom use in adolescents who have premarital sex are also still relatively low. This will further increase the rate of transmission of sexually transmitted diseases. This study shows the rate of condom use in adolescents in the city of Luwuk is $3.9 \%$ (half of the proportion of adolescents who have premarital sex). 
Table 2. HIV-Risky Sexual Behavior By Gender

\begin{tabular}{|c|c|c|c|}
\hline Variable & Males & Females & Total \\
\hline $\begin{array}{l}\text { Had sexual intercourse } \\
\text { Yes } \\
\text { No }\end{array}$ & $\begin{array}{c}22(15.8) \\
117(84.2)\end{array}$ & $\begin{array}{c}4(1.6) \\
242(98.4)\end{array}$ & $\begin{array}{c}26(6.8) \\
359(93.2)\end{array}$ \\
\hline $\begin{array}{l}\text { The first age of having sexual intercourse } \\
\text { Never } \\
\leq 12 \text { years od } \\
13-15 \text { years old } \\
16-18 \text { years old }\end{array}$ & $\begin{array}{c}117(84.2) \\
9(6.4) \\
9(6.4) \\
4(2.9)\end{array}$ & $\begin{array}{c}242(98.4) \\
0(0) \\
2(0.8) \\
2(0.8)\end{array}$ & $\begin{array}{c}359(93.2) \\
9(2.3) \\
11(2.8) \\
6(1.7)\end{array}$ \\
\hline $\begin{array}{l}\text { Number of partners when having sexual intercourse } \\
\text { Never } \\
1 \\
2 \\
3 \\
\geq 4\end{array}$ & $\begin{array}{l}117(84.2) \\
9(6.5) \\
2(1.4) \\
4(2.9) \\
7(5.0)\end{array}$ & $\begin{array}{c}242(98.4) \\
1(0.4) \\
2(0.8) \\
1(0.4) \\
0(0)\end{array}$ & $\begin{array}{c}359(93.2) \\
10(2.6) \\
4(1.0) \\
5(1.3) \\
7(1.9)\end{array}$ \\
\hline $\begin{array}{l}\text { The reason for delaying sexual intercourse } \\
\text { Have had sexual intercourse } \\
\text { Waiting for being old enough } \\
\text { Waiting for marriage first } \\
\text { At the risk of becoming pregnant } \\
\text { Risk of sexually transmitted diseases } \\
\text { Have no chance } \\
\text { Breaking religious values } \\
\text { Other reasons }\end{array}$ & $\begin{array}{c}22(15.8) \\
8(5.8) \\
58(41.7) \\
3(2.2) \\
(13(9.4) \\
3(2.2) \\
26(18.7) \\
6(4.3)\end{array}$ & $\begin{array}{c}4(1.6) \\
5(2.0) \\
141(57.3) \\
8(3.3) \\
13(5.3) \\
1(0.4) \\
43(17.5) \\
31(12.0)\end{array}$ & $\begin{array}{c}26(6.8) \\
13(3.4) \\
199(51.7) \\
11(2.9) \\
26(6.8) \\
4(1.0) \\
69(17.9) \\
37(9.5)\end{array}$ \\
\hline $\begin{array}{l}\text { Use of Condoms } \\
\text { Did not have sexual intercourse } \\
\text { Used } \\
\text { Did not use }\end{array}$ & $\begin{array}{c}105(75.5) \\
13(9.4) \\
21(15.1)\end{array}$ & $\begin{array}{l}229(93.1) \\
2(0.8) \\
15(6.1)\end{array}$ & $\begin{array}{c}334(86.8) \\
15(3.9) \\
36(9.4)\end{array}$ \\
\hline $\begin{array}{l}\text { Use of other contraception devices } \\
\text { Did not have sexual intercourse } \\
\text { Used } \\
\text { Did not use }\end{array}$ & $\begin{array}{c}116(83.4) \\
6(4.3) \\
17(12.2)\end{array}$ & $\begin{array}{l}238(96.7) \\
3(1.2) \\
5(2.0)\end{array}$ & $\begin{array}{c}356(92.0) \\
9(2.3) \\
22(5.7)\end{array}$ \\
\hline $\begin{array}{l}\text { Partners for having sexual intercourse } \\
\text { Never } \\
\text { Only female } \\
\text { Only male } \\
\text { Both genders }\end{array}$ & $\begin{array}{c}117(84.2) \\
8(5.8) \\
6(4.3) \\
8(5.8)\end{array}$ & $\begin{array}{c}242(98.4) \\
1(0.4) \\
2(0.8) \\
1(0.4)\end{array}$ & $\begin{array}{c}359(93.2) \\
9(2.4) \\
8(2.0) \\
9(2.4)\end{array}$ \\
\hline $\begin{array}{l}\text { Having knowledge of how to reject sexual invitations } \\
\text { Yes } \\
\text { No }\end{array}$ & $\begin{array}{l}54(38.8) \\
85(61.2)\end{array}$ & $\begin{array}{l}126(51.2) \\
120(48.8)\end{array}$ & $\begin{array}{l}180(46.8) \\
205(53.2)\end{array}$ \\
\hline
\end{tabular}

Table 3. Parental Supports by Gender

\begin{tabular}{|l|c|c|c|}
\hline Variable & Males & Females & Total \\
\hline Parents check the child's schoolwork & & & \\
Never & $49(35.3)$ & $80(32.5)$ & $129(33.5)$ \\
Almost never & $10(7.2)$ & $21(8.5)$ & $31(8.1)$ \\
Sometimes & $39(28.1)$ & $96(39.0)$ & $135(35.1)$ \\
Almost always & $21(15.1)$ & $17(6.9)$ & $38(9.9)$ \\
Always & $20(14.4)$ & $32(13.0)$ & $52(13.5)$ \\
\hline
\end{tabular}




\begin{tabular}{|c|c|c|c|}
\hline Variable & Males & Females & Total \\
\hline $\begin{array}{l}\text { Parents understand the problems of children never } \\
\text { Never } \\
\text { Almost never } \\
\text { Sometimes } \\
\text { Almost always } \\
\text { Always }\end{array}$ & $\begin{array}{l}34(24.5) \\
15(10.8) \\
32(23.0) \\
24(17.3) \\
34(24.5)\end{array}$ & $\begin{array}{l}49(19.9) \\
17(6.9) \\
74(30.1) \\
50(20.3) \\
56(22.8)\end{array}$ & $\begin{array}{l}83(21.6) \\
32(8.3) \\
106(27.5) \\
74(19.2) \\
90(23.4)\end{array}$ \\
\hline $\begin{array}{l}\text { Parents understand the activities of children } \\
\text { Never } \\
\text { Almost never } \\
\text { Sometimes } \\
\text { Almost always } \\
\text { Always }\end{array}$ & $\begin{array}{l}27(19.4) \\
11(7.9) \\
51(36.7) \\
23(16.5) \\
27(19.4)\end{array}$ & $\begin{array}{c}48(19.5) \\
13(5.3) \\
80(32.5) \\
34(13.8) \\
71(28.9)\end{array}$ & $\begin{array}{c}75(19.5) \\
24(6.2) \\
131(34.0) \\
57(14.8) \\
98(25.5)\end{array}$ \\
\hline $\begin{array}{l}\text { Parents check the items/contents of the child's bag } \\
\text { Never } \\
\text { Almost never } \\
\text { Sometimes } \\
\text { Almost always } \\
\text { Always }\end{array}$ & $\begin{aligned} 22 & (15.8) \\
4 & (2.9) \\
39 & (28.1) \\
28 & (20.1) \\
46 & (33.1)\end{aligned}$ & $\begin{array}{l}35(14.2) \\
14(5.7) \\
65(26.4) \\
36(14.6) \\
95(38.6)\end{array}$ & $\begin{array}{c}57(14.8) \\
18(4.7) \\
104(27.0) \\
64(1 ., 6) \\
141(36.6)\end{array}$ \\
\hline $\begin{array}{l}\text { Parents communicate with children } \\
\text { Never } \\
\text { Almost never } \\
\text { Sometimes } \\
\text { Almost always } \\
\text { Always }\end{array}$ & $\begin{aligned} 22 & (15.8) \\
4 & (2.9) \\
39 & (28.1) \\
28 & (20.1) \\
46 & (33.1)\end{aligned}$ & $\begin{array}{l}35(14.2) \\
14(5.7) \\
65(26.4) \\
36(14.6) \\
91(39.1)\end{array}$ & $\begin{array}{l}57(14.8) \\
18(4.7) \\
104(27.0) \\
64(16.6) \\
142(36.9)\end{array}$ \\
\hline $\begin{array}{l}\text { Parents undermine/demean children } \\
\text { Never } \\
\text { Almost never } \\
\text { Sometimes } \\
\text { Almost always } \\
\text { Always }\end{array}$ & $\begin{array}{c}72(51.8) \\
18(12.9) \\
35(25.3) \\
7(5.0) \\
7(5.0)\end{array}$ & $\begin{array}{c}133(54.1) \\
28(11.4) \\
70(28.5) \\
10(4.1) \\
5(2.0)\end{array}$ & $\begin{array}{c}205(53.2) \\
46(11.9) \\
105(27.3) \\
17(4.4) \\
12(3.1)\end{array}$ \\
\hline
\end{tabular}

Adolescents and young adults who actively have sexual intercourse are prone to a greater risk of HIV, partly because of low education level and sexual arousal. ${ }^{5}$ In this study, only $46.8 \%$ of adolescents knew how to reject a pre-marital sex invitation. Majority of them are (51.2\%) and only $38.8 \%$ are males. 700700 2002

Parental supports positively affect safe sexual behavior among adolescents. ${ }^{8}$ The findings of this study show that only $36.9 \%$ of parents always communicate with their children, $23.4 \%$ always can understand child's problem and only $39 \%$ of parents really know their child's activities. The relationship quality between parents and adolescents corresponds to various sexual behaviors. For example, teenagers who reported that they have active relations with parents are unlikely to be sexually active. ${ }^{11}$ The results of this study show that parents are likely to communicate with female adolescents (39\%) than male adolescents (33\%). This is in line with the tendency for adolescents who have sexual intercourse to be higher in men $(15.8 \%)$ compared to women $(1.6 \%)$. Furthermore, $5 \%$ of male adolescents have had sexual intercourse with $\geq 4$ and no data recorded for females. High parental monitoring is associated with less sexual activity and fewer partners ${ }^{(12,13)}$.

This present study also found that family involvement is associated with the sexual behavior of adolescents. Changes during the teenage period including change in sexual behavior have health consequences not only during adolescence but also during life ${ }^{(2,14)}$. The unique characteristics and importance of adolescence require explicit and specific attention in determining health 
programs and policies. Therefore, there are needs of supervision and assistance from various parties that play a role in the development phase of adolescents, including family support from parents, siblings and other family members, the neighborhood and the school environment.

Schools can develop activities that can engage parents to actively participate in child's developments both cognitive, affective and psychomotor. These are related to adolescent's perspectives on family involvement. The strategic purpose must be focused on the development of family involvement in adolescent's daily life by encouraging parents to monitor their children's whereabouts and provide personal and academic support.

Healthy premarital sexual behavior is directly affected by intention and indirectly by norms, attitudes, subjective norms, peer norms, education of mother and availabilities of health information ${ }^{(15)}$. Previous studies about sex education and sexually transmitted disease which are curriculum-based programs show that these types of programs effectively delay the initiation of premarital sex, decrease the frequency of sex, or reduce the number of sexual partners ${ }^{(16,17,18,19)}$. These programs are focused on cognitive developments namely knowledge; on sexual health issues, pregnancy, HIV and other sexually-transmitted diseases as well as preventive measures, perception; about risky pregnancy, HIV risk and other sexually-transmitted disease risks; individual values about sexuality and abstinence; Perceptions of peer norms and behavior about sex; Self-efficacy to reject sexual activity or decrease the number of sexual partners; Communication with parents or other adults about sexuality, condoms, or contraception.

\section{Conclusion}

Most of the risky sexual behavior is found in male adolescents, while the support and attention of parents are more directed at female adolescents. There are needs of health education starting from junior high school level; there is a counseling board targeted for parents of students; schools need to develop activities that engage parents to actively participate in affective and psychomotor development and can establish communication between parents and adolescents; strengthened health education through electronic media that contains persuasive advertisements to prevent health problems in adolescents.

Ethical Clearance: Our study was not directly applied on human, hence ethical clearance was not required.

Source of Funding: Self funding.

Conflict of Interest: The author declare that he has no conflict of interest.

\section{Reference}

1. Indonesian Ministry of Health. Adolescent reproductive health situation Info Datin. Ministry of Health Data and Information Center.

2. WHO. Maternal, newborn, child and adolescent health; 2018 [cited 2018 September 25] available from: http://www.who.int/maternal_child adolescent/topics/adolescence/development/

3. Saktina, P dan Satriyasa B. Characteristics of AIDS sufferers and opportunistic infections in Sanglah Central General Hospital Denpasar from July 2013 to June 2014.

4. Herawati L, Budiman J, Haryono. Adolescent Knowledge and Skills for Rejecting Drugs. Public Health. National Journal Public Health. 2018; 13 (1): $48-52$

5. Indonesian Ministry of Health. HIV/AIDS Special Cabinet Session. HIV/AIDS prevention in Indonesia. United States Agency for International Development (USAID).

6. Sia D, Onadja Y, Hajizadeh M, Heymann S.J, Brewer T.F, Nandi A. What explains gender inequalities in HIV/AIDS prevalence in subSaharan Africa? Evidence from the demographic and health surveys. BMC Public Health. 2016; 16 (1): 1-18

7. Dewi AA,. Valentina T. Relationship between Parent-Teen bonding with Independence in Adolescents at Smkn 1 Denpasar. Journal of Psychology Udayana 2013; 1(1): 181-189.

8. Lianawati F, Demartoto A, Adriani RB. Parental Communication, Peer Role and the Contextual Effect of School on Safe Sex Behavior among Adolescents in Mojokerto, East Java. Journal of Health Promotion and Behavior. 2018; 3(2): 94-99

9. Vasilenko, S.A. Age-varying associations between nonmarital sexual behavior and depressive symptoms across adolescence and young adulthood. Developmental Psychology. 2017; 53(2): 366-378

10. Shu et al. Association between age at first sexual 
intercourse and knowledge, attitudes and practices regarding reproductive health and unplanned pregnancy: a cross-sectional study. Public Health. 2016; 135: 104-113

11. Astatke et al. Use of Jessor's Theoretical Framework of Adolescent Risk Behavior in Ethiopia: Implications for HIV/AIDS Prevention. Northeast African Studies. 2000; 7 (1): 63-84

12. Jacobson, Crockett. Parental Monitoring and Adolescent Adjustment: An Ecological Perspective. University of Nebraska-LincolnDigitalCommons@ University of Nebraska-Lincoln. Available from: http://digitalcommons.unl.edu/cgi/viewcontent. cgi? article $=1230 \&$ context $=$ psychfacpub

13. Winarni, Asirin OP, Dharmawan R. Association between Self-Esteem, Self-Efficacy, Peers, Parental Controls and Sexual Behavior in Adolescentsat High School, Surakarta. Journal of Health Promotion and Behavior. 2016; 1 (1): 46-53

14. Rusmiati D., Hastono S. dolescent Attitudes towards Virginity and Sexual Behavior in Dating. Public Health, National Journal Public Health.2015; 10 (1): $29-36$
15. Tarmidi M, Demartoto A, Pamungkasari EP. Factors Associated with Pre-Marital Sexual Behavior Among Adolescents in Bima, West Nusa Tenggara: Theory of Planned Behavior. Journal of Health Promotion and Behavior. 2018;, 3(1): 78-85

16. Pinandari A., Wilopo S. Ismail D. Formal Reproductive Health Education and Indonesian Adolescent Premarital Sexual Relations Public Health, National Journal Public Health. 2015; 10 (1): 44-50.

17. Kirby D.B., Laris B.A., Rolleri L.A., Sex and HIV Education Programs : their impact on sexual behaviors of young people throughout the world. Journal of Adolescent Health. 2007; 40: 206-217

18. Palallo UD, Syafar M, Amiruddin R, Indar, Yani A. Effects of adolescent attitudes on forming intention to stop smoking. Int J Innov Technol Explor Eng. 2019;9(1).

19. Palallo UD, Syafar M, Amiruddin R, Indar, Yani A. The effect of life skill education on cigarette control in adolescents. Indian J Public Heal Res Dev. 2019;10(9). 